\title{
IPTEKS EVALUASI PEMBINAAN DAN PENGAWASAN PENYELENGGARAAN PEMERINTAHAN DAERAH PADA DINAS TENAGA KERJA DAN TRANSMIGRASI DAERAH PROVINSI SULAWESI UTARA
}

\author{
Nikita Srisilia Mawuntu ${ }^{1}$, Djeini Maradesa ${ }^{2}$ \\ ${ }^{1,2}$ Jurusan Akuntansi, Fakultas Ekonomi dan Bisnis, Universitas Sam Ratulangi, Jln. Kampus Bahu, Manado, \\ 95115, Indonesia
}

Email : nikimawuntu@gmail.com

\begin{abstract}
Good governance is a requirement in every regional and central government. To ensure the good governance has proceeded well in the unity of government, then a regulation about guidance and supervision of the regional government is arranged which regulates all about the implementation of guidance and supervision in the regional government. The Official of Manpower and Transmigration of North Sulawesi Province is one of the official agencies that has a large workload and has implemented the internal guidance and supervision in accordance with applicable regulations. This was assessed based on the Regulation of Republic of Indonesia's Government No. 12 of 2017 concerning the Guidance and Supervision of the Implementation of Regional Government. And in order to support the realization of a good government system in the North Sulawesi Province, the Department of Manpower and Transmigration continues to strive to maintain the process that has been carried out.
\end{abstract}

Keywords: good governance, guidance, supervision, regional government

\section{PENDAHULUAN}

Untuk mewujudkan pemerintahan yang bersih (good governance), selaras dengan prinsip-prinsip tata pemerintahan yang bersih dan bertanggungjawab, maka instansi pemerintahan diwajibkan untuk melaporkan segala penyelenggaraan pemerintahan yang terjadi selama periode tertentu salah satunya yaitu melalui laporan keuangan, agar dapat dijadikan bahan penilaian dan evaluasi demi terlaksananya pemerintahan kedepan yang lebih baik. Dan demi mewujudkan hal tersebut telah banyak upaya yang dilakukan pemerintah, salah satunya yaitu dengan mengadakan pengawasan dan pembinaan pada badan atau instansi pemda agar laporan yang disusun menjadi lebih berkualitas, dapat diandalkan, lebih relevan dan dapat dipercaya. Dan dengan demikian, kinerja, akuntabilitas dan transparansi dalam pengelolaan keuangan negara juga dapat menjadi lebih baik lagi dan sesuai dengan prinsip tata pemerintahan yang baik. Namun untuk mewujudkan hal tersebut tentu banyak yang harus dihadapi oleh pemerintah. Salah satu masalah krusial yang terus dihadapi oleh pemerintah negara Indonesia yaitu korupsi yang merupakan penyakit sosial dan tak henti-hentinya dilakukan oleh oknum-oknum tak berintegritas di berbagai lapisan masyarakat khususnya para pejabat publik dan pegawai negeri. Hal tersebut secara tidak langsung mengakibatkan laporan yang diberikan oleh instansi pemerintah yang seharusnya menjadi tolok ukur untuk menilai kinerja dan mutu pemerintahan justru menjadi tidak akurat dan relevan lagi jika dinilai.

Dinas Tenaga Kerja dan Transmigrasi yang selanjutnya disingkat Disnakertrans Daerah Prov. Sulut merupakan dinas di Provinsi Sulawesi Utara yang bertipe A. Dimana dinas ini melakukan fungsi pelaksanaan di daerah provinsi dengan tugas dan beban kerja yang relatif besar. Untuk itu Disnakertrans Daerah Prov. Sulut juga sangat perlu adanya 
pengawasan dan pembinaan pengelolaan pemerintahan demi menunjang terwujudnya good governance terlebih ditingkat provinsi khususnya di Provinsi Sulawesi Utara.

\section{TINJAUAN PUSTAKA}

PP RI Nomor 12 Tahun 2017. Pada PP RI Nomor 12 Tahun 2017 Tentang Pembinaan dan Pengawasan Penyelenggaraan PemDa pasal 2 ayatnya yang ke 2 dinyatakan bahwa Pengawasan dan Pembinaan Penyelenggaraan Pemda harus dilaksanakan dengan efektif serta efisien demi mempertajam kemampuan daerah dalam menopang pelaksanaan kegiatan pemerintahan agar selaras dengan perundang-undangan yang berlaku. Pembinaan umum meliputi: 1) pembinaaan lembaga-lembaga di daerah pemerintahan, 2) pembagian kegiatan kepemerintahan, 3) sistem keuangan daerah, 4) kepegawaian dalam perangkatperangkat Daerah, 5) pelayanan umum dalam daerah, 6) pembangunan-pembangunan, 7) kebijakan-kebijakan, 8) Dewan Perwakilan Rakyat Daerah dan kepala-kepala daerah, 9) kerjasama-kerjasama, dan 10) pembinaan-pembinaan lainnya yang selaras dengan peraturan undang-undang. Sedangkan Pengawasan umum meliputi: 1) pengawasan lembaga-lembaga di daerah pemerintahan, 2) penetapan kegiatan-kegiatan kepemerintahan 3) sistem keuangan daerah 4) kepegawaian dalam Perangkat Daerah 5) pelayanan umum dalam daerah 6) pembangunan-pembangunan 7) kebijakan-kebijakan 8) Dewan Perwakilan Rakyat Daerah dan kepala-kepala daerah 9) kerjasama-kerjasama dan 10) pengawasan-pengawasan lainnya yang selaras dengan peraturan undang-undang.

Good Governance Theory. Teori pemerintahan yang baik merupakan pandangan dan tujuan yang muncul dan hendak dicapai dalam suatu sistem pemerintahan yang wujud dari pencapaiannya yaitu terciptanya kemakmuran dan keadilan di tengah masyarakat.

\section{METODE DAN TEKNIS PENERAPAN IPTEKS}

\subsection{Metode Penerapan Ipteks}

Metode penerapan IPTEKS yang diterapkan yaitu menelaah proses kegiatan pengawasan dan pembinaan yang berjalan apakah sudah sesuai dengan undang-undang yang berlaku atau belum.

\subsection{Teknik Penerapan Ipteks}

Teknik penerapan IPTEKS yang dilakukan yaitu dengan menilai atau membandingkan proses kegiatan pengawasan dan pembinaan pada Disnakertrans Daerah Prov. Sulut terhadap PP RI No.12 Tahun 2017.

\section{PEMBAHASAN}

\subsection{Gambaran Singkat Objek Penerapan Ipteks}

Dinas Tenaga Kerja dan Transmigrasi Daerah Provinsi Sulawesi Utara merupakan salah satu intansi pemerintah yang ada di Provinsi Sulawesi Utara yang masuk dalam dinas tipe A, dimana dinas dengan tipe ini melakukan fungsi pelaksanaan di daerah provinsi dengan tugas dan beban kerja yang relatif besar. Disnakertrans Daerah Prov. Sulut bertugas melaksanakan segala urusan dan kepentingan provinsi Sulawesi Utara dalam hal ketenagakerjaan dan ketransmigrasian. Beralamatkan di Jalan 17 Agustus, Teling Atas, Kecamatan Wanea, Kota Manado, dinas ini memiliki visi "Terwujudnya Sulawesi Utara Berdikari Dalam Ekonomi, Berdaulat Dalam Politik, Dan Berkepribadian dalam Budaya Melalui Pembangunan Ketenagakerjaan dan Ketransmigrasian Yang Mandiri, Berdaya Saing, Dan Sejahtera" sesuai dengan visi Gubernur Sulawesi Utara saat ini.

\subsection{Pembahasan}

Penerapan Good Governance serta Pengawasan dan Pembinaan Penyelenggaraan Pemerintah Daerah di Dinas Tenaga Kerja dan Transmigrasi Daerah Provinsi Sulawesi Utara. Menurut Organization for Economic Cooperation and 
Development (OECD) dan World Bank, pemerintahan yang bersih atau good governance merupakan upaya mencegah terjadinya kesalahan dalam penempatan pos dana dan menciptakan kedisiplinan dalam hal penganggaran serta penyediaan struktur politik dan hukum yang jelas dalam kegiatan kewirausahaan; upaya mencegah terjadinya hal-hal berkaitan dengan korupsi dalam urusan politik maupun administrasi; serta peningkatan kegiatan manajemen yang solid dan bertanggung jawab dan sejalan dengan efisiensi pasar dan proses demokrasi. Sedangkan menurut United Nation Development Program (UNDP:2004), good governance yaitu penggunaan kuasa ekonomi administrasi dan politik dalam rangka mengelola segala kepentingan dan urusan negara sekaligus menjadi alat kebijakan dalam suatu negara perihal mewujudkan kesejahteraan dalam masyarakat yang utuh dan menyeluruh. Dari pengertian-pengertian tersebut dapat ditarik kesimpulan bahwa pemerintahan yang bersih atau good governance dapat diartikan sebagai proses pemerintahan yang efektif dan efisien dalam hal pemanfaatan kekuasaan dalam bidang politik, ekonomi maupun administrasi agar kepentingan negara dapat terlaksana dan berjalan dengan baik. Dan demi mewujudkan good governance, maka disusunlah aturan mengenai pembinaan dan pengawasan penyelenggaraan pemda agar mencegah terjadinya kelalaian dan kerucian dalam suatu instansi pemerintah khususnya dalam hal pelaporan keuangan. Dalam Pasal 1 ayat 1 , PP RI No. 12 Thn 2017 Tentang Pengawasan dan Pembinaan Penyelenggaraan PemDa dinyatakan Pembinaan Penyelenggaraan PemDa yaitu usaha pemerintah yang dilakukan agar setiap tujuan dari Pemerintah Daerah NKRI dapat terlaksana seperti ketentuan perundangundangan. Sedangkan ayatnya yang kedua menyatakan, Pengawasan Penyelenggaraan Pemerintah Daerah yaitu usaha pemerintah yang dilakukan untuk untuk memastikan bahwa aktivitas suatu Pemerintah Daerah sudah berjalan sesuai peraturan perundang-undangan dan telah berjalan dengan efisien dan efektif. Dinas Tenaga Kerja dan Transmigrasi Daerah Provinsi Sulawesi Utara senantiasa selalu mengusahakan agar pembinaan dan pengawasan penyelenggaraan pemda dapat diterapkan dalam kelangsungan kegiatan pemerintahan agar tujuan penyelenggaraan pemerintahan daerah dapat tercapai dengan baik dan dapat dijamin bahwa penyelenggaraan tersebut sudah berjalan dengan efektif dan efisien. Hal ini dilakukan agar dapat menunjang terwujudnya tata pemerintahan yang baik (Good Governance) diderah pemerintahan Provinsi Sulawesi Utara. Hal ini terlihat dalam upaya pembinaan seperti yang tertera pada PP RI Nomor 12 Tahun 2017, pasalnya yang ke 3 ayat 8 menyatakan bahwa pembinaan umum dan teknis dilakukan dalam bentuk:

1. Fasilitasi. Dinas Tenaga Kerja dan Transmigrasi Daerah Provinsi Sulawesi Utara selalu memfasilitasi kegiatan pegawainya dalam penyusunan RKPD dari proses perencanaan hingga proses evaluasinya. Kegiatan penyediaan fasilitas ini dilakukan meliputi: memberdayakan anggota-anggota pekerja/pegawai dalam setiap SKPD, penguatan kapasitas pegawai atau pemerintah, dan pembimbingan teknis pada setiap SKPD. Upaya fasilitasi ini dilakukan dalam betuk pendampingan dan juga pemberian prasarana dan sarana.

2. Konsultasi. Kegiatan ini dilaksanakan jika dalam pelaksanaannya dinas menemukan masalah yang mendesak atau menyangkut kepentingan masyarakat demi mendapatkan petunjuk, pertimbangan atau pendapat. Hal ini diselenggarakan oleh Menteri dan kepala instansi pemerintah non-kementerian dan dilakukan oleh Pemerintah Daerah Provinsi.

3. Pendidikan dan pelatihan. Dinas Tenaga Kerja dan Transmigrasi Daerah Provinsi Sulawesi Utara mengadakan kegiatan pendidikan dan pelatihan dalam bidang/hal: kepemimpinan, kelembagaan/kementrian/non-kementrian pemerintah, kepamongprajaan, dan teknis dan substantif pemerintah.

4. Penelitian dan pengembangan. Dinas Tenaga Kerja dan Transmigrasi Daerah Provinsi Sulawesi Utara juga melakukan penelitian dan pengembangan demi meningkatkan 
kualitas dari kebijakan-kebijakan dan program yang disusun oleh setiap bidang atau

SKPD. Kegiatan ini dilakukan mulai dari pengkajian hingga pengoperasian.

Disisi lain pengawasan umum penyelenggaraan pemerintah daerah dilakukan menurut PP RI Nomor 12 Tahun 2017 dimana dalam pasal 10 ayat 2 dinyatakan meliputi: a) pengawasan lembaga-lembaga di daerah pemerintahan, b) penetapan kegiatan-kegiatan kepemerintahan c) sistem keuangan daerah d) kepegawaian dalam Perangkat Daerah e) pelayanan umum dalam daerah f) pembangunan-pembangunan suatu daerah g) kebijakan-kebijakan dalam daerah pemerintahan h) Dewan Perwakilan Rakyat Daerah dan kepala-kepala daerah i) kerjasamakerjasama antar daerah dan j) pengawasan-pengawasan lainnya yang selaras dengan peraturan undang-undang. Pengawasan dalam bentuk teknis meliputi pengawasan terhadap:

a. Pengelolaan APBN dalam melaksanakan kegiatan pemda dibidang ketenagakerjaan dan ketransmigrasian;

b. Pencapaian dari setiap kegiatan atau standar yang telah ditentukan sebelumnya;

c. Pengaruh pelaksanaan kegiatan yang telah ditentukan terhadap kepentingan umum serta efektivitas kinerja;

d. Kepatuhan terhadap peraturan undang-undang.

\section{KESIMPULAN DAN SARAN}

\subsection{Kesimpulan}

Pembinaan dan pengawasan penyelenggaraan Pemerintahan Daerah yang seyogianya dilakukan disemua dinas pemerintahan, sudah dilakukan atau dijalankan termasuk di Disnakertrans Daerah Prov. Sulut. Pembinaan dan pengawasan yang dilakukan juga sudah selaras dengan yang tertera pada peraturan undang-undang dan sesuai dengan tata pemerintahan yang bersih.

\subsection{Saran}

Tata pemerintahan yang baik akan lebih mudah terwujud bila adanya dukungan dan kerjasama yang baik di antara setiap pegawai atau pemerintah daerah, untuk itu diharapkan bagi pemerintah Disnakertrans Daerah Prov. Sulut agar dukungan dan kerjasama satu dengan yang lain lebih ditingkatkan lagi dan kegiatan pembinaan dan pengawasan tetap dilakukan secara terus menerus demi meningkatkan kualitas pemerintahan di Provinsi Sulawesi Utara.

\section{DAFTAR PUSTAKA}

Adriansyah. 2004. "Modul Akuntansi Keuangan Pemerintah Daerah dan SKPD". Kementerian Keuangan RI Direktorat Jendral Perimbangan Keuangan.

Alfian. 2015. Tanggung Jawab Pimpinan SKPD dalam Menindaklanjuti Hasil Temuan Pemeriksaan Oleh Inspektorat Kabupaten Berdasarkan Pasal 34 Ayat (1) Peraturan Pemerintah Nomor 79 Tahun 2005 Tentang Pedoman Pembinaan Dan Pengawasan Penyelenggaraan. Jurnal NESTOR Magister Hukum Vol 1, No 1 (2015): JURNAL MAHASISWA S2 HUKUM. Universitas Tanjungpura.

Arofah, Muhammad, dkk. 2017. Pembinaan Dan Pengawasan Pemerintahan Kota Pekanbaru Terhadap Perusahaan Daerah Air Minum Tirta Siak Pekanbaru Tahun 2015. Jurnal Online Mahasiswa (JOM) Bidang Ilmu Sosial dan Ilmu Politik Vol 4, No 2:

A. Zarkasi. 2011. Pengawasan Terhadap Pengaturan Daerah. Jurnal Ilmu Hukum Vol 2, No 1. Universitas Jambi.

Etika, Dian Setyowati dan Rr. Nanik. 2016. Penerapan Prinsip-Prinsip Good Governance Di Dinas Kebersihan Dan Pertamanan Kota Surabaya Untuk Meningkatkan Partisipasi 
Masyarakat Dalam Pengelolaan Lingkungan. Jurnal Kajian Moral dan Kewarganegaraan Vol 2, No 4. Universitas Negeri Surabaya.

Humokor, Aphum. 2016. Peran Pemerintah Kecamatan Dalam Pelaksanaan Pembinaan Dan Pengawasan Penyelenggaraan Administrasi Desa Di Kecamatan Bolangitang Barat Kabupaten Bolaang Mongondow Utara. Jurnal Politico Vol 3, No 1. Universitas Sam Ratulangi Manado.

Ilyas, Husin. 2012. Pengawasan dan Pembinaan Pemerintah Pusat dalam Rangka Penyelenggaraan Pemerintah Daerah Berdasarkan UU Pemerintah Daerah. Jurnal Bina Praja: Journal of Home Affairs Governance Research and Development Agency. Ministry of Home Affairs. Vol 4 No 4.

Manengkey, Alther, Markus Kaunang dan Ismail Rachman. 2017. Peran Camat Dalam Pembinaan Dan Pengawasan Pemerintahan Desa. Jurnal Eksekutif Fakultas Ilmu Sosial dan Ilmu Pemerintahan Vol 1, No 1.

Monalisa. 2015. Evaluasi Wewenang Camat Dalam Pembinaan Dan Pengawasan Pemerintahan Desa (Studi Kasus Di Desa Pulau Busuk Jaya Kecamatan Inuman Kabupaten Kuantan Singingi Tahun 2013). Jurnal Bidang Ilmu Sosial dan Ilmu Politik Vol 2, No 1.

PP RI Nomor 60. 2008. Sistem Pengendalian Internal Pemerintah.

Peraturan Pemerintah Republik Indonesia Nomor 12. 2017. Pembinaan dan Pengawasan Penyelenggaraan Pemerintah Daerah.

Selamat, Melani Dwiyanti. 2013. Penerapan Good Governance Dalam Penyelenggaraan Pemerintahan Daerah (Suatu Studi pada Sekretariat Daerah Kabupaten Kepulauan Siau Tagulandang Biaro). Jurnal Governance Vol 5, No 1. Universitas Sam Ratulangi Manado. 